\title{
KECELAKAAN LALU LINTAS YANG DILAKUKAN OLEH ANAK YANG BELUM BERUSIA 17 TAHUN
}

\author{
Prihatin Effendi*, Ni'mathus Syaputri** \\ * Fakultas Hukum, Universitas Gresik \\ Email : peffendi5@gmail.com \\ ** Fakultas Hukum, Universitas Gresik \\ Email : nimathussyaputri@gmail.com
}

\begin{abstract}
ABSTRAK
Banyaknya kecelakaan lalu lintas yang melibatkan anak dibawah umur dan mengakibatkan hilangnya nyawa maupun harta benda seseorang menimbulkan keresahan terhadap pengguna jalan. Penelitian ini bertujuan untuk mengetahui pertanggungjawaban hukum terhadap anak yang belum berusia 17 tahun sebagai pelaku kecelakaan lalu lintas dan untuk mengetahui perlindungan hukum pidana bagi anak yang belum berusia 17 tahun sebagai pelaku kecelakaan lalu lintas. Jenis penelitian yang digunakan adalah penelitian yuridis normatif dengan pendekatan undang-undang, konseptual, dan perbandingan. Bahan hukum diperoleh dari Undang-Undang Dasar Negara Republik Indonesia Tahun 1945, Kitab UndangUndang Hukum Pidana (KUHP), Tentang Sistem Peradilan Pidana Anak, UndangUndang No. 22 Tahun 2009 tentang Lalu Lintas dan Angkutan Jalan, dan Peraturan Pemerintahan No. 43 Tahun 1993 tentang Prasarana Jalan Raya dan Lalu Lintas. Pengaturan hukum tindak pidana kecelakaan lalu lintas hingga mengakibatkan hilangnya nyawa korban diatur dalam Pasal 310 ayat (4) yakni paling lama pidana penjala selama 6 tahun dan/atau denda paling banyak Rp. 12.000.000,- dan Pelaksanaan perlindungan anak didasarkan pada Undang-Undang Dasar 1945 Pasal 28B dan berbagai peraturan perundang-undangan lainnya yang berlaku.
\end{abstract}

\section{Kata Kunci : Kecelakaan, Lalu Lintas, Anak di bawah umur 17 Tahun}

\section{Pendahuluan}

\subsection{Latar Belakang}

Kecelakaan lalu lintas yang melibatkan anak di bawah umur menimbulkan permasalahan baru dalam penegakan hukum untuk menentukan sanksi atas pertanggung jawaban oleh anak tersebut. Hal ini menjadi pokok bahasan yang selalu dibicarakan dan yang didiskusikan baik dalam media elektronik, lewat media cetak maupun dibicarakan lewat forum-forum yang bersifat nasional, transnasional di mana ujungnya bermuara pada jaminan perlindungan bagi anak dan pertanggungjawaban anak itu sendiri, dengan memperhatikan hukum positif yang berlaku dan aspek kepentingan si anak sebagai pelaku kecelakaan lalu lintas di jalan.

Dalam Undang-Undang Nomor 11 Tahun 2012 tentang sistem perlindungan anak, dalam ketentuan umum Pasal 1 ayat (3) disebutkan bahwa: "anak yang berkonflik dengan hukum yang selanjutnya disebut anak adalah anak yang telah berumur 12 (dua belas tahun, tetapi belum berumur 18 (delapan belas) tahun, yang diduga melakukan tindak pidana". 
Kecelakaan lalu lintas yang melibatkan anak dibawah umur dan mengakibatkan hilangnya nyawa maupun harta benda seseorang meresahkan pengguna jalan. Salah satu faktor penyebab kecelakaan lalu lintas tersebut adalah kurangnya pengawasan oleh orang tua serta pihak yang bertanggungjawab dalam memberikan izin mengendarai kendaraan roda empat maupun roda dua tanpa memiliki SIM. Hal tersebut mengakibatkan seorang anak telah melakukan dua pelanggaran sekaligus, yaitu tidak memenuhi syarat untuk mengendarai kendaraan di jalan umum dikarenakan belum memiliki SIM, sebagaimana diatur dalam Pasal 77 ayat (1). Peraturan tersebut mengikat setiap pengendara yang akan mengemudikan kendaraan di jalan raya. Adapun aturan yang ditegaskan tersebut bertujuan untuk menekan jumlah kecelakaan lalu lintas di jalan raya terutama anak dibawah umur yang belum memiliki SIM. Pelanggaran kedua yang dilakukan oleh anak yaitu pelanggaran pidana, karena telah menghilangkan nyawa orang lain dan menyebabkan kerugian benda.

Peraturan dalam mewujudkan keamanan, ketertiban, kelancaran berlalu lintas dan angkutan jalan dalam rangka mendukung pembangunan ekonomi dan pengembangan wilayah yang diharapkan oleh Undang-Undang Nomor 22 Tahun 2009 tentang lalu lintas dan angkutan jalan, masih belum bisa terwujud. Hal tersebut karena tingkat kecelakaan lalu lintas yang sering terjadi dan meresahkan pengguna jalan yang melibatkan anak dibawah umur serta adanya korban jiwa yang masih tinggi. Hal ini harus dipertanggungjawabkan setiap pelaku, sebagaimana sanksi yang telah diatur oleh Undang-Undang Nomor 22 Tahun 2009 tentang lalu lintas dan angkutan jalan dalam Pasal 310 ayat (3) dan ayat (4).

Undang-Undang Lalu Lintas dan Angkutan Jalan menyatakan bahwa:

Ayat (3) Setiap orang yang mengemudikan Kendaraan Bermotor yang karena kelalaiannya mengakibatkan Kecelakaan Lalu Lintas dengan korban luka berat sebagaimana dimaksud dalam Pasal 229 ayat (4), dipidana dengan pidana penjara paling lama 5 (lima) tahun dan/atau denda paling banyak Rp. 10.000.000,00 (sepuluh juta rupiah). Ayat (4) Dalam hal kecelakaan sebagaimana dimaksud pada ayat (3) yang mengakibatkan orang lain meninggal dunia, dipidana dengan pidana penjara paling lama 6 (enam) tahun dan/atau denda paling banyak Rp. 12.000.000,00 (dua belas juta rupiah) Ketentuan sanksi pelanggaran pidana yang diatur dalam pasal 310 ayat (3) dan ayat (4) dimaksudkan untuk memberikan efek jera terhadap seseorang yang lalai dalam mengendarai kendaraan bermotor sehingga mengakibatkan kecelakan lalu lintas dan mengakibatkan seseorang mengalami kerugian baik harta maupun jiwanya bahkan sampai meninggal dunia. $^{1}$

\footnotetext{
1 Mega Rosdiana, Dasar Dasar Hukum Kecelakaan Lalu Lintas, Hudapress, Semarang, 2018
} 


\begin{abstract}
Peraturan tersebut mengikat setiap pengendara yang akan mengemudikan kendaraan di jalan raya. Adapun aturan yang ditegaskan tersebut bertujuan untuk menekan jumlah kecelakaan alu lintas di jalan raya terutama anak dibawah umur yang belum memiliki SIM. ${ }^{2}$
\end{abstract}

Akan tetapi, M. Nasir mengatakan bahwa anak bukanlah untuk di hukum melainkan harus diberikan bimbingan dan pembinaan, sehingga bisa tumbuh dan berkembang sebagai anak normal yang sehat dan cerdas seutuhnya. Anak adalah anugerah Allah Yang Maha Kuasa sebagai calon generasi penerus bangsa yang masih dalam masa perkembangan fisik dan mental. Terkadang anak mengalami situasi sulit yang membuatnya melakukan tindakan yang melanggar hukum. Walaupun demikian, anak yang melanggar hukum tidak layak untuk dihukum apalagi kemudian dimasukan dalam penjara. ${ }^{3}$

Anak haruslah ditangani secara berbeda dengan orang dewasa. Untuk itu, secara paradigma model penanganan yang berlaku melalui Undang-Undang No.3 Tahun1997 tentang Pengadilan Anak, sama sebagaimana penanganan dengan orang dewasa, dengan model retributif justice, yaitu penghukuman sebagai pilihan utama atau pembalasan atas tindak pidana yang telah dilakukan. Model ini tidak sesuai, setidaknya

2 Darwin Runggolo, Peraturan Lalu Lintas edisi II, KTI Media, Surabaya, 2013

3 M. Nasir Djamil, Anak Bukan Untuk di Hukum, SinarGrafika: Jakarta, 2013, h. 1. dikarenakan dengan alasan karakteristik anak. Undang-Undang No. 23 Tahun 2002 menyebutkan: “.....untuk tumbuh berkembang secara optimal, baik fisik, mental, maupun sosial, dan berakhlak mulia..." jadi anak merupakan individu yang masih harus tumbuh dan berkembang dalam segala aspek, sehingga anak dapat menentukan pilihan perbuatan secara benar.

Penegakan hukum mengenai anak yang melakukan suatu tindak pidana telah ada undang-undang baru yaitu Undang-Undang No. 11 Tahun 2012 tentang Sistem Peradilan Anak dan untuk Undang-Undang No. 3 Tahun 1997 tentang Pengadilan Anak dianggap sudah tidak sesuai lagi dengan perkembangan dan dengan kebutuhan hukum masyarakat karena belum secara komprehensif memberikan perlindungan kepada anak yang berhadapan dengan hukum sehingga perlu diganti dengan undangundang baru. ${ }^{4}$ Perkembangannya, pelaku tindak pidana lalu lintas berkewajiban untuk memberikan santunan bagi korban kecelakaan lalu lintas, biasanya ganti kerugian terhadap korban hanya akan meringankan pidana yang dijatuhkan oleh hakim hal ini berarti dalam tindak pidana kecelakaan lalu lintas yang dilakukan oleh anak di bawah umur menimbulkan dua pertanggungjawaban yaitu pertanggungjawaban secara perdata dan pertanggungjawaban secara pidana.

4 Jogloabang, UU 11 tahun 2012 tentang Sistem Peradilan Pidana Anak, 2019, https://www.jogloabang.com/pustaka/uu-112012-sistem-peradilan-pidana-anak, diakses pada 29 Desember 2019 
Berdasarkan latar belakang di atas, peneliti ingin melakukan penelitian dengan judul "Kecelakaan Lalu Lintas yang Dilakukan oleh Anak yang Belum Berusia 17 Tahun".

\subsection{Rumusan Masalah}

1. Bagaimana pertanggung jawaban anak yang belum berusia 17 tahun sebagai pelaku kecelakaan lalu lintas?

2. Bagaimana perlindungan hukum pidana bagi anak yang belum berusia 17 tahun sebagai pelaku kecelakaan lalu lintas?

\section{Tinjauan Pustaka}

\subsection{Tindak Pidana}

Hukum pidana di Indonesia mengenal beberapa rumusan pengertian tindak pidana atau istilah tindak pidana sebagai pengganti istilah "Strafbaar Feit". Secara harfiah strafbaafeit dapat diartikan sebagai sebagian dari suatu kenyataan yang dapat dihukum.Dari pengertian tersebut, dapat ditarik kesimpulan bahwa yang dapat dihukum adalah kenyataan, perbuatan atau peristiwa, bukan pelaku.

Untuk mengatur masalah anak yang berkonflik dengan hukum, telah disahkan Undang-Undang No 11 Tahun 2012 Tentang Sistem Peradilan Anak. Dalam Undang-Undang yang terdiri atas 108 pasal itu, ditegaskan bahwa yang disebut Anak dalam kasus Anak yang Berkonflik dengan Hukum adalah anak yang telah berumur 12 (dua belas) tahun, tetapi belum berumur 18 (delapan belas) tahun yang diduga melakukan tindak pidana. ${ }^{5}$

\footnotetext{
5 Wagiati Soetodjo, Hukum Pidana Anak, Refika Aditama, Bandung, 2008, h. 70.
}

Asas yang dianut dalam Sistem Peradilan Anak di antaranya adalah: kepentingan terbaik bagi anak penghargaan terhadap pendapat anak kelangsungan hidup dan tumbuh kembang anak pembinaan dan pembimbingan anak kemerdekaan dan pemidanaan sebagai upaya terakhir dan penghindaran pembalasan.

\subsection{Kecelakaan Lalu Lintas}

Di dalam Undang-Undang No. 22 tahun 2009 Lalu Lintas didefinisikan sebagai gerak kendaraan dan orang di ruang lalu lintas jalan, sedang yang dimaksud dengan ruang lalu lintas jalan adalah prasarana yang diperuntukan bagi gerak pindah kendaraan, orang dan/atau barang yang berupa jalan atau fasilitas pendukung. Operasi lalu lintas di jalan raya ada empat unsur yang saling terkait yaitu pengemudi, kendaraan, jalan dan pejalan kaki.

Kecelakaan tidak terjadi kebetulan, melainkan ada sebabnya. Oleh karena ada penyebabnya, sebab kecelakaan harus dianalisis dan ditemukan, agar tindakan korektif kepada penyebab itu dapat dilakukan serta dengan upaya preventif lebih lanjut kecelakaan dapat dicegah. Menurut UU LLAJ (Lalu Lintas dan Angkutan Jalan), kecelakaan lalu lintas adalah "suatu peristiwa di jalan yang tidak diduga dan disengaja melibatkan kendaraan dengan atau tanpa pengguna jalan lain yang mengakibatkan korban manusia dan/atau kerugian harta benda"6.

Kecelakaan lalu lintas selalu menimbulkan kerugian baik materiil maupun non materiil. Untuk itu,

${ }^{6}$ Buya Zarkainn, Hukum dan Tata Tertib dalam Berlalu Lintas, JMpublisher, Surabaya, 2018, h. 56 
pelaku penyebab kecelakaan lalu lintas harus diberikan hukuman pidana. Adapun ketentuan pidana pelaku kecelakaan lalu lintas diatur dalam beberapa pengaturan undang-undang. Dalam Pasal 229 UU LLAJ (Lalu Lintas dan Angkutan Jalan), kecelakaan lalu lintas digolongkan menjadi 3, yaitu:

1. Kecelakaan Lalu Lintas ringan, merupakan kecelakaan yang mengakibatkan kerusakan kendaraan dan/atau barang.

2. Kecelakaan lalu lintas sedang, merupakan kecelakaan yang mengakibatkan luka ringan dan kerusakan kendaraan dan/atau barang.

Kecelakaan lalu lintas berat, merupakan kecelakaan yang mengakibatkan korban meniggal dunia atau luka berat.

Secara umum mengenai kewajiban dan tanggung jawab pengemudi, Pemilik Kendaraan Bermotor, dan/atau perusahaan angkutan ini diatur dalam Pasal 234 ayat (1) UU lalu lintas dan angkutan jalan yang berbunyi: "Pengemudi, pemilik kendaraan bermotor, dan/atau perusahaan angkutan umum bertanggung jawab atas kerugian yang di derita oleh penumpang dan/atau pemilik barang dan/atau pihak ketiga karana kelalaian pengemudi”.

Namun dalam Pasal 234 ayat (3) UU Lalu lintas dan Angkutan Jalan ketentuan sebagaimana dimaksud di atas tidak berlaku jika:

1. Adanya keadaan memaksa yang tidak dapat dielakkan atau di luar kemampuan pengemudi;

2. Disebabkan oleh perilaku korban sendiri atau pihak ketiga; dan/atau

3. Disebabkan gerakan orang dan/atau hewan
walaupun telah diambil
tindakan pencegahan
Dalam Pasal 236 UU Lalu Lintas dan Angkutan Jalan. pihak yang menyebabkan terjadinya kecelakaan lalu lintas wajib Mengganti kerugian yang besarannya ditentukan berdasarkan putusan pengadilan. Kewajiban mengganti kerugian in dapat dilakukan di luar pengadilan jika terjadi kesepakatan damai diantara para pihak yang terlibat. Jadi, dapat disimpulkan bahwa bentuk pertanggungjawaban atas kecelakaan lalu lintas yang hanya mengakibatkan kerugian materi tanpa koban jiwa adlah dalam bentuk penggantian kerugian.

Menurut Sianturi, mengemukakan bahwa dalam hal menentukan apakah kecelakaan yang mengakibatkan kerugian materi tanpa korban jiwa merupakan tindak pidana atau bukan, maka tindakan dinyatakan sebagai tindak pidana jika memenuhi unsur-unsur. ${ }^{7}$
1. Subjek
2. Kesalahan

3. Bersifat melawan hukum(dari tindakan) Suatu tindakan yang dilarang atau diharuskan oleh undang-undang/perundangan dan terhadap pelanggarnya diancam dengan pidana.

4. Waktu, tempat dan keadaan. Jika dikaitkan dengan kecelakaan lalu lintas sebagaimana tersebut di atas, baik kecelakaan lalu lintas ringan, sedang maupun berat adalah termasuk tindak pidana. Hal ini merujuk pada ketentuan Pasal 230 UU

${ }^{7}$ Hardiansyah Rendy, Tinjauan Lalu Lintas Berdasarkan Hukum Perundang-undangan, Libertypress, Yogyakarta, Libertypress, 2015, h. 52 . 
Lalu Lintas dan Angkutan Jalan yang berbunyi: "Perkara Kecelakaan Lalu Lintas sebgaimana dimaksud dalam Pasal 229 ayat (2), ayat (3), dan ayat (4) diproses dengan acara peradilan pidana sesuai dengan ketentuan peraturan perundang-undangan.

Ketentuan Pidana Pada Kecelakaan Lalu Lintas Menurut Undang-Undang LLAJ (Lalu Lintas dan Angkutan Jalan):

1. Pasal 310: Setiap orang yang mengemudikan kendaraan bermotor yang karena kelalaiannya mengakibatkan kecelakaan lalu lintas dengan:

a. Kerusakan kendaraan dan/atau barang, dipidana dengan pidana penjara paling lama 6 (enam) bulan dan/atau denda paling banyak Rp. 1.000.000,00 (satu juta rupiah).

b. Korban luka ringan dan kerusakan kendaraan dan/atau barang, dipidana dengan pidana penjara paling lama 1 (satu) tahun dan/atau denda paling banyak Rp. 2.000.000,00 (dua juta rupiah).

c. Korban luka berat, dipidana dengan pidana penjara paling lama 5 (lima) tahun dan/atau denda paling banyak Rp. 10.000.000,00 (sepuluh juta rupiah), dalam hal kecelakaan tersebut mengakibatkan orang lain meninggal dunia dipidana dengan pidana penjara paling lama 6 (enam) tahun dan/atau denda paling banyak Rp. 12.000.000,00 (dua belas juta rupiah).

2. Pasal 311: Setiap orang yang dengan sengaja mengemudikan kendaraan bermotor dengan cara dan keadaan yang membahayakan bagi nyawa atau barang dipidana dengan pidana penjara paling lama 1 (satu) tahun atau denda paling banyak Rp. 3.000.000,00 (tiga juta rupiah). Dalam hal perbuatan mengakibatkan kecelakaan lain dengan:

a. Keruskan kendaraan dan/atau barang, pelaku dipidana dengan pidana penjara paling lama 2 (dua) tahun atau denda paling banyak Rp. 4.000.000,00 (empat juta rupiah).

b. Korban luka ringan dan kerusakan kendaraan dan/atau barang, dipidana dengan pidana penjara paling lama 4 (empat) tahun atau denda paling banyak Rp. 8.000.000,00 (delapan juta rupiah).

c. Korban luka berat, dipidana dengan pidan penjara paling lama 10 (sepuluh) tahun atau denda paling banyak Rp. 20.000.000,00 (dua puluh juta rupiah), dalam hal kecelakaan tersebut mengakibatkan orang lain meninggal dunia dipidana dengan pidana penjara paling lama 12 (dua belas) tahun atau denda paling banyak Rp. 24.000.000,00 (dua puluh empat juta rupiah).

Dalam BAB XXI Kitab 
Undang-undang Hukum Pidana (selanjutnya disingkat KUHPidana) yang menyebabkan mati atau lukaluka karena kealpaan terdapat pada pasal sebagai berikut:

1. Pasal 359 KUHPidana: Barang siapa karena kesalahannya (kealpaannya) menyebabkan orang lain mati, diancam dengan pidana penjara paling lama 5 (lima) tahun atau pidana pidana kurungan paling lama 1 (satu) tahun

2. Pasal 360 KUHPidana:

a. Ayat 1 : "Barang siapa karena kesalahannya (kealpaannya)

menyebabkan orang lain mendapat luka-luka berat, diancam dengan pidana penjara paling lama 5 (lima) tahun atau pidana kurungan paling lama 1 (satu) tahun."

b. Ayat 2 : Barang siapa karena kesalahannya (kealpaannya)

menyebabkan orang lain luka-luka sedemikian rupa sehingga timbul penyakit atau halangan menjalankan pekerjaan jabatan atau pencarian selama waktu tertentu, diancam dengan pidana penjara paling lama 9 (sembilan) bulan atau pidana kurungan paling lama 6 (enam) bulan atau pidana denda paling tinggi Rp. 4.500.000,00 (empat juta lima ratus ribu rupiah).

\subsection{Undang-Undang Nomor 3 Tahun 1997 tentang Pengadilan Anak}

Dalam Undang-Undang Nomor 3 tahun 1997 tentang Pengadilan Anak diatur terkait aturan-aturan tentang pengadilan atas perbuatan menyimpang dari norma hukum yang berlaku yang dilakukan oleh anak. Kelemahan Undang-Undang Nomor 3 Tahun 1997 Tentang Pengadilan Anak adalah tidak mengatur tentang diversi untuk mengalihkan perkara anak di luar jalur peradilan formal sehingga anak mendapatkan stigmatisasi. Undang-undang ini belum mengakomodasi model keadilan restoratif. Sehingga paradigma filosofi Undang-Undang Nomor 3 Tahun 1997 tentang Pengadilan Anak dapat dikatakan menganut pendekatan yuridis formal dengan menonjolkan penghukuman (retributive). Menurut Hermien, "Undang-Undang Nomor 3 tahun 1997 tampaknya tidak cukup membawa perubahan bagi nasib anak sebagai pelaku tindak pidana (Juvenile Deliquency)"8 "Model peradilan anak retributif tidak pernah mampu memberikan kerangka kerja yang memadai bagi berkembangnya sistem peradilan anak." 9

\subsection{Undang-undang Nomor 11} Tahun 2012 tentang Sistem Peradilan Pidana Anak

Dalam Undang-Undang Nomor 11 Tahun 2012 tentang Sistem Peradilan Anak diatur segala sesuatu terkait sistem peradilan segala

\footnotetext{
${ }^{8}$ Hermien Hadiati Koeswadji, Perkembangan Macam-MAcam Pidana dalam Rangka Pembangungan Hukum Pidana, Bandung, PT. Citra Aditya, 2006, h. 121.

9 Angger Sigit Pramukti dan Fuady Primaharsya, Sistem Peradilan Pidana Anak, Medpress Digital, Yogyakarta, 2014, h. 39
} 
perbuatan melawan hukum yang berlaku yang dilakukan oleh anak. Diterbitkannya Undang-Undang Nomor 11 Tahun 2012 Tentang Sistem Peradilan Pidana Anak yang mengarah kepada pendekatan keadilan restoratif yang lebih mengutamakan kepentingan anak sebagai pelaku dalam perbaikan masa depan dan diri anak, penghukuman sebagai jalan terakhir dan dalam pidana tambahan juga dalam undang-undang ini terdapat pemenuhan kewajiban adat, artinya undang-undang ini mengakui adanya keberlakuan aturan adat. ${ }^{10}$ Azas yang dianut dalam sistem peradilan pidana anak di antaranya adalah kepentingan terbaik bagi anak; penghargaan terhadap pendapat anak; kelangsungan hidup dan tumbuh kembang anak; pembinaan dan pembimbingan anak; perampasan kemerdekaan dan pemidanaan sebagai upaya terakhir; dan penghindaran pembalasan. Sistem peradilan pidana anak pun wajib mengutamakan pendekatan keadilan restoratif, serta wajib diupayakan diversi dengan tujuan mencapai perdamaian antara korban dan anak; ${ }^{11}$ menyelesaikan perkara anak di luar proses peradilan; menyelesaikan perkara anak di luar proses peradilan; menghindarkan anak dari perampasan kemerdekaan; mendorong masyarakat untuk berpartisipasi; dan menanamkan rasa tanggung jawab kepada anak. ${ }^{12}$

\section{Metode Penelitian}

\subsection{Jenis Penelitian}

${ }^{10}$ Ibid

11 John Wiliian, Law to Protecting Child, JoshuePress, California, 2009

${ }^{12}$ E.Y. Kanter, et al, Asas-asas Hukum Pidana Anak di Indonesia dan Penerapannya, ferderalpress, Jakarta, 2013
Jenis penelitian yang digunakan adalah penelitian yuridis normatif. Penelitian hukum yuridis normatif dilakukan dengan cara menelaah teori-teori, konsepkonsep, dan asas hukum serta peraturan perudang-undangan dan sering kali hukum dikonsepsikan sebagai apa yang tertulis dalam peraturan perundang-undangan (Law in book) atau hukum yang dikonsepsikan sebagai kaidah atau norma yang merupakan patokan berperilaku masyarakat terhadap apa yang dianggap pantas.

\subsection{Pendekatan Penelitian}

Penelitian ini menggunakan pendekatan undang-undang (statute approach), pendekatan konseptual, dan pendekatan perbandingan.

\subsection{Teknik Analisis Bahan Hukum}

Teknik analisis bahan hokum dilakukan dengan mengumpulkan bahan-bahan hokum terlebih dahulu, lalu melakukan seleksi data, dan kemudian klasifikasi data.

\section{Pembahasan}

\subsection{Pertanggungjawaban Anak sebagai Pelaku Kecelakaan Lalu Lintas}

Sebagaimana telah disebutkan bahwasanya keberadaan anak merupakan amanah sekaligus karunia yang diberikan oleh Tuhan Yang Maha Esa, yang senantiasa harus kita jaga karena dalam dirinya melekat harkat, martabat dan hak- hak sebagai manusia yang harus dijunjung tinggi. Hak asasi anak merupakan bagian yang termuat dalam Undang-Undang Dasar Negara Republik Indonesia Tahun 1945 dan konvensi Perserikatan Bangsa-Bangsa tentang hak-hak anak. Dari sudut pandang kehidupan berbangsa dan bernegara, anak adalah 
masa depan bangsa dan generasi penerus cita-cita bangsa, sehingga setiap anak berhak atas kelangsungan hidup, tumbuh dan berkembang, berpartisipasi serta berhak atas perlindungan dari tindak kekerasan dan diskriminasi serta hak sipil dan kebebasan.

Peradilan Anak sebagai media pertanggungjawaban pidana yang dilakukan anak berbeda halnya dengan peradilan pada umumnya mengingat hak istimewa yang dimiliki anak. Perlakuan terhadap anak perlu dibedakan karena pada saat itu darah, tubuh dan jiwa si anak sedang mengalami perkembangan. Dengan demikian, dapat dikatakan bahwa si anak sedang dalam keadaan labil. Jadi ada sesuatu yang berbeda ketika kita berbicara tentang anak. Anak bukanlah orang dewasa karena itu dia tidak bisa disamakan dengan miniatur dari orang dewasa, karena itu harus diberikan perlakuan yang berbeda, juga karena anak itu sendiri dalam masa pertumbuhan dan harus ada proteksi sejak awal. Hal itulah yang menyebabkan adanya pembedaan perlakuan terhadap anak.

Pengadilan anak dibentuk sebagai upaya pembinaan dan perlindungan dalam rangka menjamin pertumbuhan dan perkembangan fisik, mental, dan sosial anak secara utuh, serasi, dan seimbang. Oleh karenanya, ketentuan mengenai penyelengaraan pengdilan bagi anak dilakukan secara khusus. Meskipun demikian, hukum acara yang berlaku (KUHAP) diterapkan pula dalam acara pengadilan anak, kecuali ditentukan lain dalam undang-undang Nomor 3 Tahun 1997.

Ketentuan

mengenai penyelenggaraan pengadilan anak dilakukan secara khusus. Berdasarkan
Pasal 15 UU No.4 Tahun 2004 tentang Kekuasaan Kehakiman, dapat diketahui bahwa Pengadilan Khusus hanya dapat dibentuk dalam salah satu lingkungan peradilan sebagaiman dimaksud dalam Pasal 10 yang diatur dengan undang-undang. Sesuai dengan hal ini Peradilan anak merupakan Peradilan khusus, merupakan spesialisasi dan difensiasinya di bawah Pengadilan umum.

Peradilan anak diatur berdasarkan undang-undang Nomor 3 Tahun 1997 tantang Pengadilan Anak, menyatakan bahwa ${ }^{13}$

1. Batas umur anak nakal yang dapat dijatuhkan ke sidang anak adalah sekurang-kurangnya 8 (delapan) tahun tetapi belum mencapai umur 18 (delapan belas) tahun dan belum pernah kawin.

2. Aparat penegak hukum yang berperan dalam proses persidangan anak yaitu Penyidik adalah Penyidik anak, Penuntut Umum adalah Penuntu Umum Anak , dan Hakim adalah Hakim Anak. (vide Pasal 1 butir 5,6, dan 7)

3. Hakim, Penuntut Umum, Penyidik, dan Penasehat Hukum serta petugas lainnya dalam sidang anak tidak memakai toga ataupun pakaian dinas.(vide Pasal 6)

4. Untuk melindungi kepentingan anak pada prinsipnya pemeriksaan perkara anak dilakukan dalam sidang tertutup, kecuali dalam hal tertentu dapat dilakukan dalam sidang terbuka, misalnya perkara pelanggaran lalu lintas dan pemeriksaan perkara ditempat

13 Maidin Gultom, Perlindungan Hukum Terhadap Anak, PT Refika Aditama, Jakarta, 2008, h. 76 
kejadian perkara. (vide Pasal 8 ayat(1) dan (2).

5. Ketentuan pidan yang adapat dijatuhkan kepada anak yang melakukan tindak pidana antara lain sebagai berikut:

a. Pidana penjara yang dapat dijatuhkan paling lama $1 / 2$ (satu perdua) dari maksimum ancaman pidana penjara bagi orang dewasa (vide Pasal 26 ayat 2)

b. Apabila melakukan tindak pidana yang diancam dengan pidana mati atau pidana penjara seumur hidup maka pidan penjara yang dapat dijatuhkan paling lama 10 (sepuluh) tahun. (vide Pasal 26 ayat (2)).

c. Apabila belum mencapai umur 12 (dua belas) tahun melakukan tindak pidana yang diancam pidana mati atau pidana penjara seumur hidup maka anak nakal tersebut dijatuhi pidana berupa "menyerahkan kepada negara untuk mengikuti pendidikan, pembinaan, dan latihan kerja". (vide Pasal 26 ayat (3) Jo. Pasal 24 ayat (1) huruf b.

d. Apabila belum mencapai umur 12 (dua belas) tahun, melakukan tindak pidana yang tidaka diancam pidana mati atau tidak diancam pidanapenjara seumur hidup maka anak nakal tersebut dijatuhi salah satu tindakan.(vide Pasal 26 ayat (4) Jo.Pasal 24).

e. Pidana kurungan yang dapatdijatuhkan paling banyak $1 / 2$ (satu perdua) dari makasimum ancaman pidana denda bagi orang dewasa (vide Pasal 27).

f. Apabila pidana denda tidak dapt dibayara maka diganti dengan wajib latihan kerja paling lama 90 hati kerja dan lama latihan kerja tidak lebih 4 jam sehari serta tidak dilakukan pada malam hari. (vide Pasal 28 ayat (2)).

g. Pidana bersyarat dapat dijatuhkan oleh Hakim apabila pidan penjara yang dijatuhkan paling lama 2(dua) tahun.(vide Pasal 29 ayat (1)

Kecelakaan lalu lintas jalan yang mengakibatkan pengendara kendaraan bermotor meninggal dunia diatur dalam Pasal 310 ayat (4) Undang-Undang Nomor 22 Tahun 2009 yang menyebutkan bahwa setiap orang yang mengemudikan kendaraan bermotor yang karena kelalaiannya mengakibatkan kecelakaan lalu lintas yang mengakibatkan orang lain meninggal dunia, dipidana dengan pidana penjara paling lama 6 (enam) tahun dan/ atau denda paling banyak Rp.12.000.000,00 (dua belas juta rupiah). Menurut ketentuan hukum pidana, seseorang atau subjek hukum pidana lain yang telah terbukti melakukan tindak pidana harus mempertanggungjawabkan

perbuatannya baik yang dilakukan karena sengaja atau karena kelalaian. Dalam kecelakaan lalu lintas yang terjadi karena kelalaian pengendara kendaraan bermotor yang mengakibatkan orang lain meninggal dunia dalam kenyataannya dapat dilakukan oleh siapa saja baik orang dewasa maupun anak.

Berdasarkan hasil pengamatan penulis bahwa pertanggungjawaban anak dalam perkara kecelakaan lalu lintas lebih banyak menuju pada 
penyelesaian perdata daripada penyelesaian pidana. Hal ini terjadi karena aparat hukum dalam hal ini polisi memberi pengecualian terutama pada anak pelaku kecelakaan lalu lintas. Hal tersebut dikarenakan anak adalah aset negara yang harus dilindungi haknya, baik hak untuk berkembang, pendidikan, kebebasan dan lain-lain. Polisi sebagai pihak penengah yang mempertemukan kedua belah pihak untuk mengambil suatu kesepakatan dalam penyelesaian perkara lalu lintas ini, apabila hal tersebut tidak ada titik temunya atau kesepakatan untuk berdamai maka polisi langsung melanjutkan pemeriksaan dan melimpahkan perkara kepengadilan.

Segi hukum pidana bagi anak yang mengendarai kendaraan bermotor hingga menghilangkan nyawa korban sebagaimana yang disebut dalam Pasal 310 ayat (4) UU No. 22 Tahun 2009 tentang Lalu Lintas dan Angkutan Jalan (“UU LLAJ"):

(3) Setiap orang yang mengemudikan Kendaraan Bermotor yang karena kelalaiannya mengakibatkan Kecelakaan Lalu Lintas dengan korban luka berat sebagaimana dimaksud dalam Pasal 229 ayat (4), dipidana dengan pidana penjara paling lama 5 (lima) tahun dan/atau denda paling banyak Rp. 10.000.000,00 (sepuluh juta rupiah).

(4) Dalam hal kecelakaan sebagaimana dimaksud pada ayat (3) yang mengakibatkan orang lain meninggal dunia, dipidana dengan pidana penjara paling lama 6 (enam) tahun dan/atau denda paling banyak Rp12.000.000,00 (dua belas juta rupiah).
Ancaman pidana tersebut berlaku bagi mereka yang sudah dewasa, sedangkan ancaman pidana penjara bagi anak yang melakukan tindak pidana adalah setengah dari maksimum ancaman pidana penjara bagi orang yang sudah dewasa sebagaimana yang telah diatur dalam Pasal 26 ayat (1) Undang-Undang Nomor 3 Tahun 1997 tentang Pengadilan Anak ("UU Pengadilan Anak"). Dengan demikian, anak yang mengemudikan kendaraan bermotor karena kelalaiannya hingga mengakibatkan orang lain meninggal dunia dipidana dengan pidana penjara setengah dari ancaman pidana bagi orang dewasa (enam tahun), yakni paling lama tiga tahun penjara.

Dalam Undang-Undang Lalu Lintas dan Angkutan Jalan mengatur mengenai pelanggaran dan juga sanksi terhadap pelaku pelanggaran lalu lintas. Bahwa dalam kasus kecelakaan lalu lintas yang mengakibatkan matinya orang lain, maka kepada keluarga korban sepatutnyalah mendapatkan santunan dari si pelaku. Hal ini berkaitan dengan nilai-nilai kepatutan, kelaziman, adat-istiadat, dan keagamaan yang berlaku dalam masyarakat Indonesia.Santunan tersebut terutama ditujukan untuk biaya penguburan dan biaya-biaya lainnya yang secara nyata diperlukan oleh keluarga korban untuk pengurusan jenazah korban.

Hal itu berkaitan dengan ketentuan Pasal 235 ayat (1) UndangUndang No. 22 Tahun 2009 yang menentukan : "Jika korban meninggal dunia akibat kecelakaan Lalu Lintas sebagaimana dimaksud dalam Pasal 229 ayat (1) huruf c, Pengemudi, pemilik, dan/ atau Perusahaan Angkutan Umum wajib "memberikan bantuan kepada ahli waris korban 
berupa biaya pengobatan dan/atau biaya pemakaman dengan tidak menggugurkan tuntutan perkara pidana".

Demikian pula dalam hal kecelakaan lalu lintas yang mengakibatkan luka berat (Pasal 310 ayat (3) Undang-Undang No. 22 Tahun 2009) atau kerugian materiil terhadap korban, selayaknyalah diberikan santunan biaya pengobatan atau ganti rugi kepada korban. Hal ini juga bersesuaian dengan ketentuan Pasal 235 ayat (2) UndangUndang No. 22 Tahun 2009 yang menentukan: "Jika terjadi cedera terhadap badan atau kesehatan korban akibat Kecelakaan Lalu Lintas sebagaimana dimaksud dalam Pasal 229 ayat (1) huruf $b$ dan huruf $c$, pengemudi, pemilik, dan/atau Perusahaan Angkutan Umum wajib memberikan bantuan kepada korban berupa biaya pengobatan dengan tidak menggugurkan tuntutan perkara pidana".

Dasar pemidanaan dalam tindak pidana lalu lintas yang dilakukan anak sehingga menyebabkan korban meninggal dunia adalah pertimbangan hukum putusan, dimana unsur-unsur pasal dibuktikan. $^{14}$ Adapun unsur-unsur pasal yang menjadi dasar pemidanaan adalah:

a. Pasal 310 ayat 3 Undang-undang Nomor 22 Tahun 2009 tentang Lalu Lintas dan Angkutan Jalan Unsur-unsur Pasal 310 ayat 3 Undangundang Nomor 22 Tahun 2009 Tentang Lalu Lintas dan Angkutan Jalan:

1. Setiap Orang;

14 Gatot Supramono, Surat Dakwaan dan Putusan Hakim Yang Batal Demi Hukum, Djambatan, Jakarta, 1991, h. 60.
2. Mengemudi kendaraan bermotor

3. Karena kelalaiannya menyebabkan kecelakaan lalu lintas;

4. Mengakibatkan orang lain meninggal dunia.

b. Pasal 310 ayat 4 Undang-undang Nomor 22 Tahun 2009 Tentang Lalu Lintas dan Angkutan Jalan Unsur-unsur Pasal 310 ayat 4 Undangundang Nomor 22 Tahun 2009 Tentang Lalu Lintas dan Angkutan Jalan:

1. Setiap Orang;

2. Mengemudi kendaraan bermotor

3. Karena kelalaiannya menyebabkan kecelakaan lalu lintas

4. Mengakibatkan orang lain meninggal dunia.

Berdasarkan paparan Undangundang No. 3 Tahun 1997 tentang Pengadilan Anak maka dapat dipahami bahwa pelanggaran terhadap ketentuan ini tidak akan mengakibatkan putusan batal demi hukum tetapi akan menciptakan suasana yang menyeramkan bagi anak sehingga melanggar hak-hak anak. Putusan hakim dapat berupa sanksi hukum atau bebas dari segala tuntutan hukum, sedangkan sanksi hukum dapat berupa pidana atau tindakan. Pada kasus tindak pidana lalu lintas yang dilakukan anak sehingga menyebabkan kematian, oleh Hakim diputuskan bahwa terdakwa terbukti bersalah karena kelalaiannya mengemudi kendaraan bermotor mengakibatkan kecelakaan lalu lintas yang menyebabkan orang lain meninggal dunia dan menjatuhkan sanksi berupa pidana penjara dan denda dengan ketentuan apabila denda 
tersebut tidak dibayar maka diganti dengan pidana kurungan.

Sanksi pidana yang dijatuhkan hakim menurut penulis sudah tepat karena perbuatan terdakwa dilakukan bukan atas dasar kesengajaan tetapi karena kelalaian terdakwa. Masa penjara yang diberikan dapat mendidik anak agar lebih berhati-hati agar perbuatan serupa tidak diulanginya kembali. Sanksi pidana tersebut merupakan jalan keluar atas tindak pidana yang dilakukan oleh anak. Di satu sisi memberikan hukuman atas kesalahan dan efek jera agar tidak mengulangi lagi di sisi lain dapat menghindari terjadinya trauma pada anak atas hukuman yang diberikan.

Kata diversi berasal dari bahasa Iggris diversion yang bermakna penghindaran atau pengalihan. ${ }^{15}$ Berdasarkan Pasal 7 ayat 1 Undang-Undang Nomor 11 tahun 2012 tentang Sistem Peradilan Pidana Anak, diversi adalah pengalihan penyelesaian perkara anak dari proses peradilan pidana ke proses di luar peradilan pidana. Pelaksanaan diversi memiliki tujuan yaitu (1) Mencapai perdamaian antara korban dan anak, (2) Menyelesaikan perkara anak di luar proses peradilan, (3) Menghindarkan anak dari perampasan kemerdekaan, (4) Mendorong masyarakat untuk berpartisipasi dan (5) Menanamkan rasa tanggung jawab kepada anak.

Tujuan dari diversi adalah untuk mendapatkan cara menangani pelanggran hukum di luar pengadilan atau sistem peradilan pidana formal. Ada kesamaan tujuan diskresi dengan

15 DS. Dewi, Mediasi Penal: Penerapan Restorative Justice Di Pengadilan Anak Indonesia, Indie Publishing, Depok, 2011, h. 51. diversi. Pelaksanaan diversi dilatar belakangi keinginan menhindari efek negatif terhadap jiwa dan perkembangan anak oleh keterlibatannya dengan sistem peradilan pidana. Pelaksanaan diversi oleh aparat penegak hukum didasari oleh kewenangan aparat penegak hukum yang disebut diskresi. ${ }^{16}$

Penerapan diversi dalam hal anak berhadapan dengan hukum wajib dilaksanakan dalam setiap tingkat pemeriksaaan mulai dari tingkat penyidikan, penuntutan dan pemeriksaan perkara anak di pengadilan. Diversi dilaksanakan dalam hal tindak pidana yang dilakukan diancam dengan pidana penjara di bawah 7 (tujuh) tahun, bukan merupakan pengulangan tindak pidana, dan dilakukan terhadap anak yang berusia 12 (dua belas) tahun keatas.

Pelaksanaan proses diversi dilaksanakan melalui musyawarah. Berdasarkan Pasal 1 angka (1) Perma Nomor 4 Tahun 2014, musyawarah diversi adalah musyawarah antara para pihak yang melibatkan anak dan orang tua/walinya, korban dan/atau orang tua/walinya, pembimbing kemasyarakatan, dan pekerja sosial profesional serta dapat melibatkan tenaga kesejahteraan sosial dan/atau masyarakat.

\subsection{Perlindungan Hukum Pidana bagi Anak sebagai Pelaku Kecelakaan Lalu Lintas}

Dalam peradilan pidana anak terdapat beberapa unsur yang saling terkait yaitu: Penyidik anak, Penuntut Umum Anak, Hakim Anak, dan

16 Marlina, Pengantar Konsep Diversi dan Restorative Justice dalam Hukum Pidana, USU Press, Medan, 2010, h. 2. 
Petugas Pemasyarakatan Anak. Peradilan Pidana Anak yang adil memberikan perlindungan terhadap anak, baik sebagai tersangka, terdakwa, maupun sebagai terpidana/narapidana. Komite Hak Anak (Committee on the Rights of the Child) menandaskan bahwa sistem peradilan pidana anak merupakan sistem peradilan pidana yang dipisahkan secara khusus bagi anak sehingga anak dapat menikmati perlindungan hukum (due process) dan hak asasi yang melekat padanya. ${ }^{17}$

Sanksi pidana yang dijatuhkan kepada anak harus didasarkan pada kebenaran, keadilan, dan kesejahteraan anak. Penjatuhan pidana atau tindakan merupakan suatu tindakan yang harus mempertanggung jawabkan dan bermanfaat bagi anak. Anak bukanlah untuk dihukum, melainkan harus diberikan bimbingan dan pembinaan, sehingga bisa tumbuh dan berkembang sebagai anak normal yang sehat dan cerdas seutuhnya.

Berkaitan dengan hal tersebut, Sistem peradilan pidana anak wajib mengutamakan pendekatan keadilan Restoratif (Pasal 5 ayat (1) UndangUndang No 11 tahun 2012 Tentang Sistem Peradilan Pidana Anak) dan Wajib diupayakan Diversi (Pasal 5 ayat (3). Diversi dan restorative justice merupakan penyelesaian tindak pidana secara tidak formal untuk menghindari trauma bagi anak selama proses peradilan. Tindakan ini dimaksudkan untuk memberikan perlindungan terhadap semua pihak sehingga tercapai keadilan. Dengan demikian undang-undag telah

17 Lilik Mulyadi, Pengadilan Anak di Indonesia Teori, Praktik, dan Permasalahannya, Penerbit Mandar Maju, Bandung, 2005, h. 8-9. memberikan jalan keluar bagi penegakkan hukum anak yang melakukan tindak pidana.

Pelaksanaan perlindungan anak harus didasarkan pada UndangUndang Dasar 1945 Pasal 28B dan berbagai peraturan perundangundangan lainnya yang berlaku. Terkait tindakan hukum yang dilakukan terhadap anak sama saja dengan yang dilakukan orang dewasa selama mereka melakukan pelanggaran lalu lintas karena berkendara tidak dilengkapi suratsurat. Namun, jika terjadi kecelakaan lalu lintas, maka ada proses hukum yang berbeda terhadap anak yaitu dengan adanya hak-hak perlindungan hukum bagi anak. Agar sanksi pidana terhadap pelanggaran lalu lintas dapat ditegakkan namun keadilan bagi pelaku dan/atau korban dapat terwujud, salah satu wujud dari Restorative Justice (keadilan restoratif) adalah dimunculkannya lembaga penal mediation, yaitu penyelesaian perkara pidana melalui jalur mediasi.

Mediasi penal sebagai alternatif sistem peradilan saat ini sangat diperlukan karena merupakan salah satu proses penyelesaian sengketa yang dianggap lebih cepat, murah dan sederhana. Dalam penyelesaian perkara anak yang berkonflik dengan hukum, dasar hukum dari kewenangan hakim untuk melakukan mediasi penal terdapat pada ketentuan Pasal 64 huruf g Undang-Undang No. 35 Tahun 2014 Tentang Perlindungan Anak diatas yang menyebutkan bahwa penghindaran dari penangkapan, penahanan atau penjara, kecuali sebagai upaya terakhir dan dalam waktu yang paling singkat. 
Hal mengenai mediasi penal ini juga terdapat dalam pasal 16 ayat (3) Undang-Undang Perlindungan Anak No. 35 tahun 2014 yang menyebutkan bahwa penangkapan, penahanan, dan penjatuhan hukuman pidana penjara bagi anak adalah upaya terakhir ${ }^{18}$

Penyelesaian secara musyawarah dalam menyelesaikan kasus tindak pidana pelanggaran lalu lintas oleh anak, dipertimbangkan meskipun diketahui bahwa anak melakukan tindak pidana tersebut. Dengan Keadilan Restoratif kasus pelanggaran tindak pidana anak ini sangat dimungkinkan penyelesaiannya dengan cara yang tidak mengakibatkan timbulnya pembalasan dan hal ini penting untuk menjaga atau menghindarkan anak agar anak tidak mengalami trauma yang dapat mempengaruhi perkembangan kehidupannya di masa depan. ${ }^{19}$

Penyelesaian terhadap anak memang dirasa sangat bersifat khusus. Hal tersebut dikarenakan sifat anak dilihat dari usia anak-anak belum memiliki kematangan baik secara fisik maupun mental sehingga anak belum dapat membedakan hal yang baik dan benar dan cenderung melakukan segala sesuatunya secara spontan tanpa berpikir panjang. Diperlukannya perhatian khusus terlebih bagi anak yang hidup ${ }^{20}$ dalam lingkungan di mana lingkungan tersebut menghasilkan suatu hubungan dengan penuh kekerasaan dan kecenderungan

18 Maidin Gultom, Perlindungan Hukum Terhadap Anak, PT. Refika Aditama, Bandung, 2014, hal. 193

19 Indra Subagja , Detik News, http://news.detik.com/read/

2013/09/14/112951/2358745/10/14 September 2013, diakses pada 2 Juni 2020.

${ }^{20}$ Bagong Suyatno, Masalah Sosial Anak, Kencana, Jakarta, 2010, h. 5. untuk tidak peduli atau menelantarkan yang terjadi antara anak dengan orang dewasa sekitarnya.

Anak merupakan faktor terpenting dalam kemajuan maupun perkembangan suatu negara. Sebagai generasi penerus bangsa yang memiliki peranan penting, maka dibutuhkan seorang anak dengan mental yang kuat, serta kemampuan intelektual yang cukup merupakan hal yang wajib untuk meneruskan suatu citacita bangsa yang hakiki. $^{21}$ Sehingga penyelesaian perkara anak harus benarbenar memperhatikan kondisi anak di masa yang akan datang.

Diversi menjadi jawaban atas tujuan dari penyelesaian perkara anak secara adil. Hanya saja dalam menerapkan diversi diperlukan beberapa persyaratan tertentu. Diversi baru dapat dilakukan14 dengan melihat usia anak, sifat perbuatan tersebut apakah baru pertama kali dilakukan atau merupakan bentuk pengulangan, diberlakukan dalam tindak pidana ringan, adanya persetujuan dari korban dan kesepakatan para pihak, serta kerelaan masyarakat untuk mendukung proses diversi.

Catatan penting dalam penyelesaian diversi kemudian adalah diversi tidak lah selalu berhasil dilakukan. Diversi hanya dapat diupayakan dan ditawarkan kepada para pihak berdasarkan kesepakatan dan terpenuhinya syarat untuk dilakukan diversi. Diversi yang berhasil membawa konsekuensi bahwa para pihak harus melaksanakan keputusan tersebut dengan kerelaan

${ }^{21}$ Darwan Prinst, Hukum Anak

Indonesia, Citra Aditya Bakti, Bandung, 1997, h. 4 . 
dan keikhlasan sesuai dengan butirbutir kesepakatan yang tertuang dalam bentuk penetapan yang dikeluarkan oleh Ketua Pengadilan Negeri setempat. Apabila kesepakatan dan syarat diversi tidak terpenuhi maka perkara tersebut akan dikembalikan dan akan diproses secara formal.

Perkembangannya seorang anak tersebut tergantung sepenuhnya pada masyarakatnya dan perkembangan zaman. Jika masyarakat suatu lingkungan baik maka perkembangan anak kemudian menjadi baik. Begitu juga sebaliknya, apabila lingkungan masyarakatnya menjadi buruk maka anak akan ikut menjadi pribadi yang tidak baik. Begitu juga dengan kecelakan lalu lintas yang terjadi sebagai salah satu bentuk kenakalan anak dapat terjadi karena adanya faktor internal yang dipengaruhi oleh keacuhan orang tua dalam memberikan perhatian dan faktor eksternal dalam masyarakat yang terjadi karena keinginan anakanak untuk ikut-ikutan sehingga anak terpengaruh dan melakukan kenakalan.

Undang-undang

Sistem

Peradilan Pidana Anak memberikan hak-hak terhadap anak sebagai korban. Anak korban maupun saksi berhak untuk memperoleh rehabilitasi baik medis maupun sosial, dijamin keselamatannya baik fisik, mental dan sosial serta tetap mendapatkan informasi mengenai perkembangan perkaranya. Perlindungan anak ${ }^{22}$ sebagai korban dapat pula berupa ganti kerugian, restitusi dan kompensasi.

${ }^{22}$ Rena Yulia, Viktimologi:

Perlindungan Hukum terhadap Korban Kejahatan, Graha Ilmu, Yogyakarta, 2010, h. 178-180.

\begin{abstract}
Anak sebagai pelaku tentu memiliki kewajiban untuk mempertanggungjawabkan

perbuatannya. Karena sifat khusus anak maka dalam mempertanggungjawabkan

perbuatannya anak akan melalui tahap dalam sistem peradilan pidana sepanjang diversi gagal atau tidak memenuhi syarat untuk diterapkan. Dalam tataran tertentu baik anak yang masuk dalam ranah diversi maupun non diversi wajib diperhatikan hakhak serta kewajibannya dalam rangka memenuhi tujuan dari perlindungan hukum terhadap anak yang berhadapan dengan hukum.
\end{abstract}

\section{Penutup}

\subsection{Kesimpulan}

a) Pengaturan hukum tindak pidana kecelakaan lalu lintas hingga mengakibatkan hilangnya nyawa korban diatur dalam Pasal 310 ayat (4) yakni paling lama pidana penjala selama 6 tahun dan/atau denda paling banyak $\mathrm{Rp}$. 12.000.000,-.

b) Pelaksanaan perlindungan anak didasarkan pada Undang-Undang Dasar 1945 Pasal 28B dan berbagai peraturan perundangundangan lainnya yang berlaku. Agar sanksi pidana terhadap pelanggaran lalu lintas dapat ditegakkan namun keadilan bagi pelaku dan/atau korban dapat terwujud, salah satu wujud dari Restorative Justice (keadilan restoratif) adalah dimunculkannya lembaga penal mediation.

\subsection{Saran}

1. Sebaiknya orang tua harus lebih berhati-hati dalam mendidik anak, sekiranya belum terlalu penting khususnya pada alat transportasi apabila anak memang belum fasih 
dan belum cukup umur jangan sampai lalai untuk mengingatkan agar melarang anak untuk menaiki alat transportasi seperti sepeda motor ataupun mobil.

2. Sosialisasi dari aparat penegak hukum maupun sekolah lebih ditingkatkan dengan penyampaian yang baik pula, supaya anak mengerti dan faham akan suatu aturan, tata tertib berkendara yang baik terkait dengan sarana rambu lalu lintas yang sering di sepelekan bagi pengguna jalan pada umunya.

3. Terbitnya Undang-Undang Nomor 11 Tahun 2012, memang dari segi penerapan hukum terkait dengan tindak pidana anak, anak mendapatkan perlindungan hukum berupa diversi yaitu tindak pidana dilakukan oleh anak sebelum genap berumur 18 (delapan belas) tahun, di mana diversi sekarang mulai dari pihak penyidik sudah mempunyai wewenang untuk menyeselesaikan perkara di luar pengadilan, dengan bentuk permusyawarahan kepada kedua pihak korban dan pelaku atas perkara tersebut. Mengenai proses diversi perlu pengawasan kuhsus terhadap jalanya diversi, karena proses diversi ini dapat dijadikan sebagai celah untuk melakukan tindakan KKN. Maka bagi masingmasing pihak perlu berhati-hati baik segai pihak korban maupun pelaku agar tidak mudah terhasut oleh oknum nakal.

\section{DAFTAR PUSTAKA}

\section{Buku dan Jurnal}

Dewi, D.S, Mediasi Penal: Penerapan Restorative Justice Di Pengadilan Anak Indonesia, Indie Publishing, Depok, 2011.
Djamil, M. Nasir, "Anak Bukan Untuk di Hukum", SinarGrafika, Jakarta, 2013.

Gultom, Maidin, Perlindungan Hukum Terhadap Anak, PT Refika Aditama, Jakarta, 2008.

Kanter, E. Y. Et al., "Asas-asas Hukum Pidana Anak di Indonesia dan Penerapannya", Ferderal press, Jakarta, 2013

Koeswadji, Hermien Hadiati, "Perkembangan MacamMacam Pidana dalam Rangka Pembangungan Hukum Pidana", PT. Citra Aditya, Bandung, 2006.

Marlina, Pengantar Konsep Diversi dan Restorative Justice dalam Hukum Pidana, USU Press, Medan, 2010.

Mulyadi, Lilik, Pengadilan Anak di Indonesia Teori, Praktik, dan Permasalahannya, Penerbit Mandar Maju, Bandung, 2005.

Pramukti, Angger Sigit., dan Fuady Primaharsya, "Sistem Peradilan Pidana Anak", Medpress Digital, Yogyakarta, 2014.

Prinst, Darwan, Hukum Anak Indonesia, Citra Aditya Bakti, Bandung, 1997.

Rendy, Hardiansyah, "Tinjauan Lalu Lintas Berdasarkan Hukum Perundang-undangan", Libertypress, Yogyakarta, 2015.

Rosdiana, Mega, "Dasar Dasar Hukum Kecelakaan Lalu Lintas", Hudapress, Semarang, 2018.

Runggolo, Darwin. "Peraturan Lalu Lintas", edisi II, KTI Media, Surabaya, 2013.

Soetodjo, Wagiati, "Hukum Pidana Anak", Refika Aditama, Bandung, 2008. 
Supramono, Gatot, Surat Dakwaan dan Putusan Hakim Yang Batal Demi Hukum, Djambatan, Jakarta, 1991.

Suyatno, Bagong, Masalah Sosial Anak, Kencana, Jakarta, 2010.

Wiliian, John, "Law to Protecting Child", JoshuePress, California, 2009.

Yulia, Rena, Viktimologi: Perlindungan Hukum terhadap Korban Kejahatan, Graha Ilmu, Yogyakarta, 2010.

Zarkainn, Buya, "Hukum dan Tata Tertib dalam Berlalu Lintas", Jmpublisher, Surabaya, 2018.

\section{Website}

$$
\begin{aligned}
& \text { Jogloabang, UU } 11 \text { tahun } 2012 \\
& \text { tentang Sistem Peradilan } \\
& \text { Pidana Anak, 2019, } \\
& \text { https://www.jogloabang.com/p } \\
& \text { ustaka/uu-11-2012-sistem- } \\
& \text { peradilan-pidana-anak, diakses } \\
& \text { pada } 29 \text { Desember } 2019 .
\end{aligned}
$$

